\title{
A new genus and species of owlfly from eastern and southern Africa (Neuroptera: Ascalaphidae)
}

\author{
Bruno MICHEL ${ }^{1, *} \&$ Mervyn W. MANSELL ${ }^{2}$ \\ ${ }^{1}$ CIRAD, CBGP, 755 avenue du Campus Agropolis, \\ CS 30016, 34988 Montferrier-sur-Lez, France. \\ ${ }^{2}$ Department of Zoology and Entomology, University of Pretoria, \\ Pretoria 0002, South Africa. \\ ${ }^{*}$ Corresponding author: bruno.michel@cirad.fr \\ ${ }^{2}$ Email: mansel@mweb.co.za \\ ${ }^{1}$ urn:1sid:zoobank.org:author:722321B3-407F-490A-9020-ECDB1E835F76 \\ ${ }^{2}$ urn:lsid:zoobank.org:author:7BD4656A-A2E3-426B-A9B5-DBED06E28284
}

\begin{abstract}
The genus Dorsomitus Tjeder, 1992, is considered a nomen nudum. Dorsomitus gen. nov. is described and validated here. A new combination, Dorsomitus neavei (Kimmins, 1949) gen. et comb. nov. is proposed, Dorsomitus tjederi gen. et sp. nov. is described, and Disparomitus neavei Kimmins, 1949 , is designated as type species of the genus Dorsomitus gen. nov.
\end{abstract}

Keywords. Biodiversity, Ascalaphidae, Suhpalacsini, Africa, Afrotropical Region.

Michel B. \& Mansell M.W. 2018. A new genus and species of owlfly from eastern and southern Africa (Neuroptera: Ascalaphidae). European Journal of Taxonomy 413: 1-12. https://doi.org/10.5852/ejt.2018.413

\section{Introduction}

Ascalaphidae Lefèbvre, 1842 are a small family of Neuroptera Linnaeus, 1758 comprising about 430 species belonging to 100 genera (Oswald 2015), mainly distributed in tropical regions. Larvae are ambushhunters that live on vegetation or under rocks. Most adults are crepuscular or nocturnal, but some species are typically diurnal, including the genera Libelloides Schäffer, 1763, and Deleproctophylla Lefèbvre, 1842, in temperate regions. Adults are active predators and capture prey in flight (New 1986; Tjeder 1992). Species of Ascalaphid are currently grouped into three subfamilies: Haplogleniinae Newman, 1853, whose adults have entire eyes and long clubbed antennae, Ascalaphinae Lefèbvre, 1842, with eyes divided by a transverse furrow and long clubbed antennae, and Albardiinae van der Weele, 1909, comprised of only one Neotropical species with entire eyes and short clubbed antennae. Approximately 150 species of Ascalaphidae, belonging to 44 genera, have been recorded from sub-Saharan Africa (van der Weele 1909; Tjeder 1992; Tjeder \& Hansson 1992; Mansell 2000; Michel 2012; Michel \& Akoudjin 2013; Prost 2013).

Little constructive advance has been made regarding the tribal arrangement since the monograph of van der Weele (1909) and the publications of Navás $(1913,1919)$. The most recent classification of the 
African species into tribes was initiated by Tjeder \& Hansson (1992) but, unfortunately, the passing of the first author prematurely terminated the study, leaving the characterization of the tribes consequently confused and unsatisfactory.

At the end of his life Tjeder suffered from ill-health that prevented him from completing his manuscript on the Ascalaphidae of the Afrotropical Region. After several years, this manuscript was finalized by three of Tjeder's colleagues - H. Andersson, C. Hansson and L. Cederholm - who assigned a number in the main text to some new taxa that Tjeder was planning to describe. Before his state of health deteriorated too much to continue his work, Tjeder prepared figures to illustrate these new taxa, but did not associate them with formal descriptions, which would have completed the work as the author intended. Among the new taxa that Tjeder intended to describe was a genus named "n. gen. 5" by the assistants. The genus name Dorsomitus appears only in two figure legends provided by Tjeder (Tjeder \& Hansson 1992: figs 50-51), in the form "Dorsomitus sp.", with no precise details of the corresponding species. Therefore, we consider Dorsomitus Tjeder, 1992 to be a nomen nudum. This publication validates the genus name Dorsomitus, proposing Disparomitus neavei Kimmins, 1949 as type species, and also describes a new species of Dorsomitus gen. nov.

\section{Material and methods}

The type specimens of all species have been examined. For the examination of the male terminalia and genitalia, the last abdominal segments were cut from the abdomen and treated with a cold $5 \% \mathrm{KOH}$ solution to facilitate examination and dissection. The segments were then rinsed in distilled water and stored in glycerine in a microvial for further examination and preservation. All of the images were taken using the technical platform of CBGP (Centre de Biologie pour la Gestion des Populations). Habitus photographs were taken using a digital camera Canon ${ }^{\circledR}$ EOS 450D equipped with a Canon ${ }^{\circledR}$ macro lens EF-S $60 \mathrm{~mm}$ and fixed on a stand. The light source was as described by Aberlenc (1980). Photographs of terminalia and genitalia were taken using EntoVision multifocus system (JVC Digital Camera KYF75U+Leica Z16 APO A zoom).

We continue to use the terms 'gonarcus' and 'parameres' as defined by Tjeder (1977) for purposes of direct comparability and stability in the nomenclature of the male terminalia, although these characters have been renamed gonocoxites $9+11$ by Aspöck \& Aspöck (2008).

The present state of knowledge and limited material available do not permit a definite association of the males with females. Consequently, the two sexes are considered separately.

The old names of the countries or localities recorded on the labels of the examined specimens are mentioned in brackets after the actual denomination.

\section{Abbreviations}

Institutions

The specimens examined are deposited in the following institutions (names of the curators in brackets):

MNHN = Muséum national d'Histoire naturelle, Paris, France (J. Legrand and A. Mantilleri)

NHMUK = Natural History Museum, London, United Kingdom (B. Price)

SANC = South African National Collection of Insects, Pretoria, South Africa (M.W. Mansell)

\footnotetext{
Morphology

$\mathrm{e}=$ left ectoproct

gp $=$ gonarcus-parameres complex

$\mathrm{p}=$ right pulvinus

$\mathrm{s}=$ seta
} 


\title{
Results
}

\author{
Class Insecta Linnaeus, 1758 \\ Order Neuroptera Linnaeus, 1758 \\ Family Ascalaphidae Lefèbvre, 1842 \\ Subfamily Ascalaphinae Lefëbvre, 1842 \\ Dorsomitus Michel \& Tjeder† gen. nov. \\ urn:1sid:zoobank.org:act:6E1F9444-5B07-41AB-9B14-7BC3C6C72E98
}

Figs $1-3$

Dorsomitus Tjeder, 1992: 25-26, figs 50-51. Nomen nudum.

\section{Type species}

Disparomitus neavei Kimmins, 1949, here designated.

\section{Diagnosis}

The genus Dorsomitus gen. nov. is well characterized by the combination of the following characters: the markings on the third abdominal sternite in both sexes (Figs 1E, 2F, 3C, F) and the shape of the first abdominal tergite of males being prolonged into a strong, apically forked projection directed backwards with the apex of each prong covered by dense short black hairs directed downwards (Figs 1C-D, 2C-E).

\section{Description}

HEAD. Frons with a tuft of white erect setae on each side and a tuft of brownish setae between antennal bases. Antenna straight, shorter than distance between base of the forewing and pterostigma. Third segment of labial palpus without sensory pit.

THorax. Lateral and ventral surface of thorax covered with long white setae (Figs 1B, 2B). Wings hyaline. Pterostigma short, yellowish to light-brown with four cross-veins heavily bordered with dark brown.

Legs. Femora covered by long white hairs. Tibiae with dark brown spine-like hairs ventrally, each side with long white hairs and dorsal surface glabrous.

AвDOMEN. First abdominal tergite of males prolonged into a strong, apically forked projection directed backwards with apex of each prong covered by dense short black hairs directed downwards (Figs 1CD, 2C-E). Sternite 2 with the posterior margin indented in the middle (Figs 1E, 2F, 3C, F). Sternite 3 with its surface slightly wavy transversally, with a shiny black S-shaped area at the antero-lateral angles and two longitudinal black sinuate lines (Figs 1E, 2F, 3C, F), which disappear gradually on the following segments. Male ectoprocts moderately developed laterally and downwards (Fig. 2G). Gonarcus-parameres complex as in Fig 2H-J. Parameres not prolonged downwards by a carina (Fig. 2H, J). Female with head and thorax of same coloration as male (Fig. 3A, D). First abdominal tergite not developed dorsally, divided along the midline into a pair of dorso-lateral plates united by membranous tissue (Fig. 3A-B, D-E). Third abdominal segment shorter than in male (Fig. 3C, F). Coloration of abdomen as in Fig. 3.

\section{Tribal position}

It is not possible to assign the genus Dorsomitus gen. nov. to a known tribe with certainty, given the lack of recent taxonomic work. The most closely related tribes seem to be Suhpalacsini and Acmonotini described by van der Weele (1909). However, according to this author, in the former tribe the ectoprocts 
are small and not expanded ("klappen-förmige Appendices") and the basal tergite of the abdomen is never developed into a cone-like projection, and in the latter tribe it is the second and not the first abdominal tergite which is dorsally developed. Navás (1919) grouped both tribes in Suhpalacsini to include his new genus Fillus Navás, 1919 from Argentina, considering it closely related to Disparomitus van der Weele, 1909 and Acmonotus MacLachlan, 1873. The genus Fillus is characterized by the first abdominal tergite elongated and folded horizontally on the second and third abdominal segments. The extremity of the protuberance is weakly forked, but is devoid of spines. The genus Dorsomitus gen. nov. could fit Navás' description, but this clade is probably not monophyletic and further investigation is needed to provide comprehensive phylogenetic relationships between the genera, and to assign Dorsomitus gen. nov. to any existing tribe with certainty.

Dorsomitus neavei (Kimmins, 1949) gen. et comb. nov.

Fig. 1

Disparomitus neavei Kimmins, 1949: 13, fig. 5.

\section{Diagnosis}

Male

Prongs of the forked projection of abdominal segment 1 of male as long as wide (Fig. 1D). Side and dorsal part of the abdominal tergites 2 and 3 of male with slender erect brown setae (Fig. 1D-E).

\section{Material examined}

\section{Holotype}

MALAWI: O̊, Mulanje ("Nyasaland, Mlanje"), -16.03, 35.50, alt. 634 m, 4 Dec. 1912, S.A. Neave leg. (NHMUK 1913-140) (Fig. 1A).

\section{Remarks}

The male of $D$. neavei was described in detail by Kimmins (1949). In addition, the mesothoracic prescutum manifests a dark oval marking divided medially by a narrow longitudinal clear line (Fig. 1A). Dorsal part of mesoscutum with an elongate dark marking. Lateral and ventral part of thorax lighter than the dorsal part (Fig. 1B). First abdominal tergite developed into a bifurcate projection with the prongs as long as wide. Its surface is striated (Fig. 1D). Lateral surfaces of the second and third abdominal tergites covered with slender erect setae, similar setae also present dorsally (Fig. 1C). Third abdominal sternite yellowish with two basal black shiny areas and two sinuate dark lines (Fig. 1E). Gonarcus-parameres complex as in Fig. 1F.

\section{Distribution}

Known from Malawi (Fig. 4).

Dorsomitus tjederi Michel gen. et sp. nov. urn:1sid:zoobank.org:act:666BFC9D-4117-426E-880C-B0CAD5E9E600

Fig. 2

\section{Diagnosis}

\section{Male}

Prongs of the forked projection of first abdominal segment twice as long as wide (Fig. 2D-E). Lateral surface of abdominal tergites 2 and 3 covered with short black spines (Fig. 2C-D). 


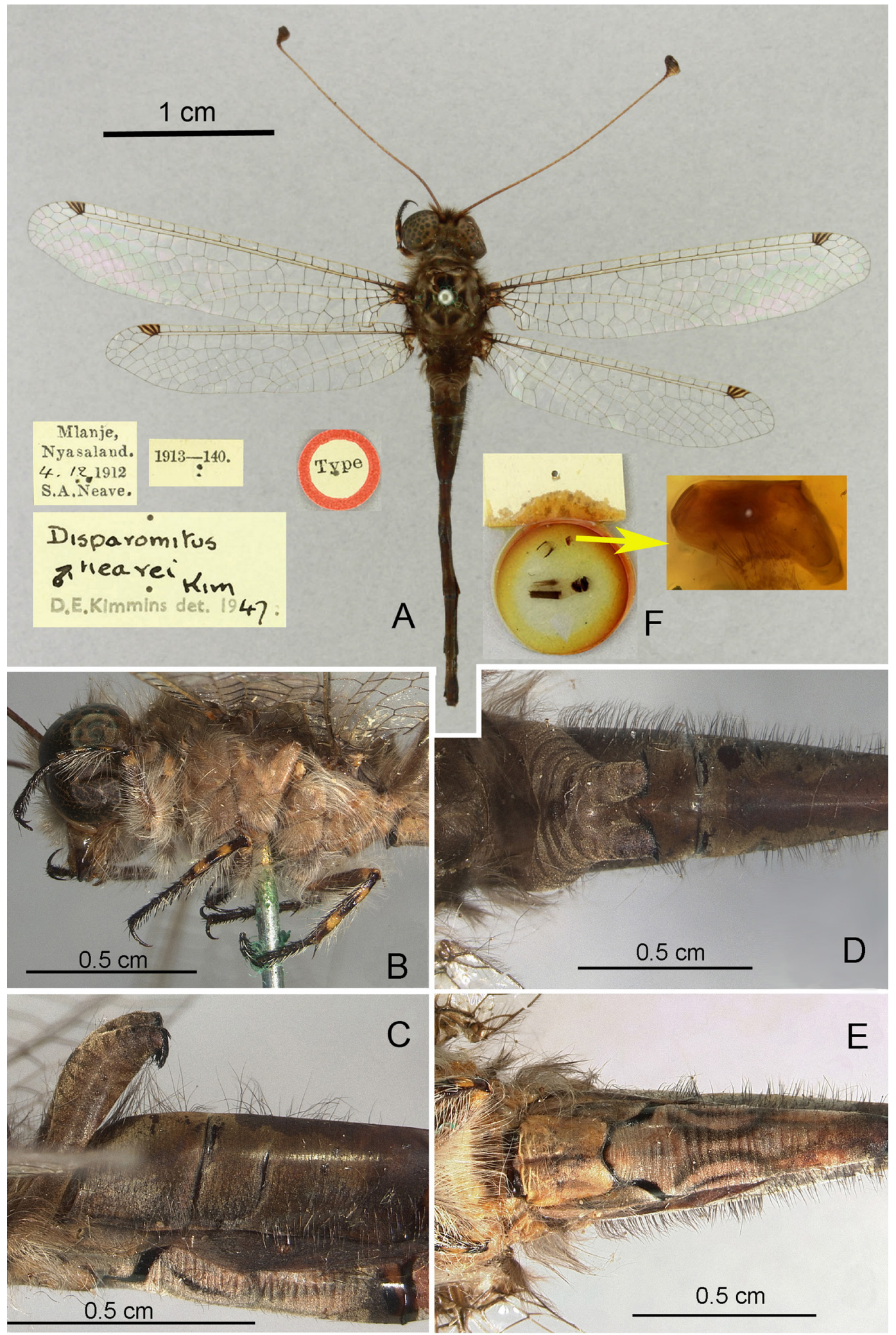

Fig. 1. Dorsomitus neavei (Kimmins, 1949) gen. et comb. nov., holotype, ô (NHMUK 1913-140). A. Habitus with associated labels. B. Lateral view of head and thorax. C. First to third abdominal tergites, left lateral view. D. Same as previous, dorsal view. E. Base of abdomen, ventral view. F. Original mounting of terminalia and genitalia. 


\section{Etymology}

The first author dedicates this species to the late Dr. Bo Tjeder in gratitude for his huge contribution to the knowledge of Neuroptera.

\section{Material examined}

\section{Holotype}

ZIMBABWE: Ô, Marondera ("Rhodesia, Marandellas"), -18.19, 31.55, alt. 1640 m, Nov. 1961, “Disparomitus neavei det. D.E Kimmins 1963” (NHMUK 1963-439) (Fig. 2A).

\section{Other specimens}

MALAWI: 10 , Chisasira Forest Reserve, -11.85, 34.08, 25 Dec. 2001, R.J. Murphy leg. (SANC NEUR05937).

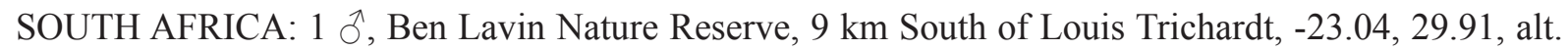
950 m, 8-14 Dec. 2000, M. Krüger leg. (SANC NEUR09310); 1 §, same but 8 Dec. 2000 (SANC NEUR09310); 1 ô, Bluegums Poort Farm, -22.97, 29.88, alt. 1445 m, 15 Oct. 1999, J. Joannou leg. (SANC NEUR05778); 1 ð’, D’Nyala Nature Reserve, -23.75, 27.83, alt. 893 m, 17 Dec. 1987, E. Van der Linde leg. (SANC NEUR00775); 1 đ̂, Manoutsa Resort, -24.4, 30.62, alt. 504 m, 24 Nov. 1981, R.G. Oberprieler leg. (SANC NEUR00080); 1 ð̄, same but 24 Nov. 1981, M.W. Mansell leg. (SANC NEUR00083); 1 J, Pafuri, -22.43, 31.21, alt. 216 m, 24 Dec. 1973, H. \& A. Braack leg. (SANC NEUR09295); 1 ठ̊, same but 6 Dec. 1986, L.E.O. Braack leg. (SANC NEUR08750).

ZIMBABWE: 1 ô, Arcturus, -17.78, 31.32, 7 Nov. 1999, A.J. Gardiner leg. (SANC NEUR09311); 1 §., Harare, Glenborne, -17.25, 31.03, 3 Dec. 1992, A.J. Gardiner leg. (SANC NEUR09312); 1 ð, Lawrenceville, -19.03, 32.73, alt. 1500 m, 6 Dec. 1994, N.J.S. Duke leg. (SANC NEUR01985).

\section{Description}

\section{Male}

HEAD. Frons black with luteous margins to eyes. Labrum and clypeus yellowish. Tufts of hairs between bases of antennae brownish. Antennae brown with yellowish mark on external apical part of each antennomere. This mark (not clearly visible on all the specimens) is more visible on the last segments. Segments of the club yellowish, bordered with brown apically.

Thorax. Grey to yellowish-brown. Prescutum of mesothorax with dark oval marking divided medially by a narrow longitudinal clear line. Dorsal part of mesoscutum with an elongate dark marking (Fig. 2A). Lateral and ventral part of thorax testaceous, lighter than the dorsal part, covered with silky white hairs (Fig. 2B). Legs dark brown with apex of femora yellow and two yellow markings on the dorsal surface of tibiae (Fig. 2B). Tarsi dark brown.

AbDomen. Prongs of the forked projection of abdominal segment 1 of male twice as long as wide (Fig. 2D-E). Lateral surfaces of abdominal tergites 2 and 3 covered with short black erect spines (Fig. 2C-D). Dorsal area of same tergites glabrous (Fig. 2C). Second abdominal tergite with two basal black shiny areas and two longitudinal sinuate dark lines (Fig. 2F). Ectoprocts extended laterally with one apical stout black seta (Fig. 2G). Subgenital plate convex, yellowish laterally, bordered with brown, tapering to a sub-rounded apex. Gonarcus-parameres complex as in Fig. 2H-J. Parameres not extended downwards by a carina (Fig. 2H, J). Pulvini well developed, lacking setimere (Fig. 2G).

\section{Distribution}

Known from South Africa, Zimbabwe and Malawi (Fig. 4). 


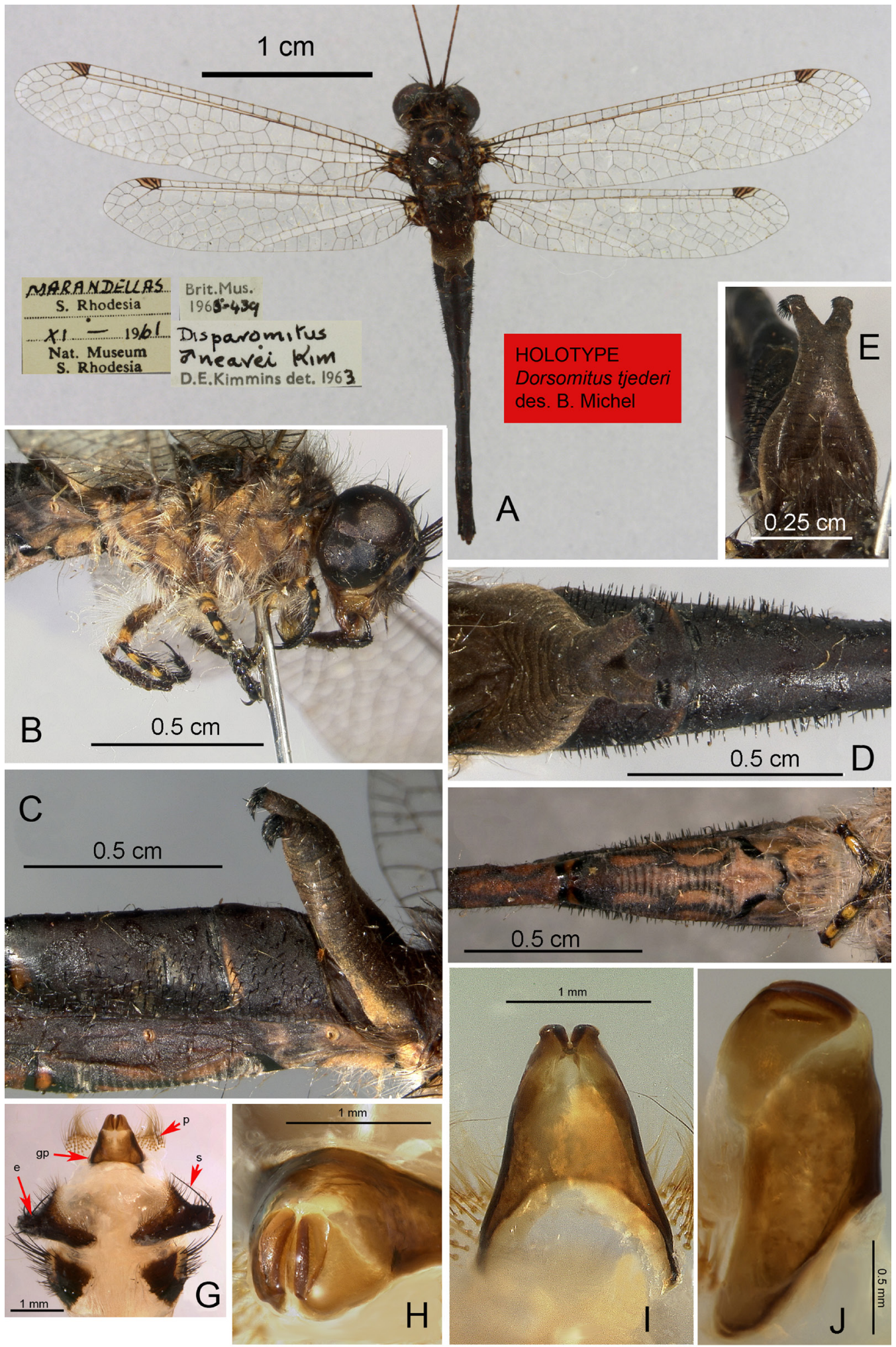

Fig. 2. Dorsomitus tjederi gen. et sp. nov., holotype, $\widehat{\curlywedge}$ (NHMUK 1963-439). A. Habitus with associated labels. B. Lateral view of head and thorax. C. First to third abdominal tergites, right lateral view. D. Same as previous, dorsal view. E. First abdominal tergite, front view. F. Base of abdomen, ventral view. G. Terminalia and genitalia, dorsal view. H. Gonarcus-parameres complex, caudal view. I. Same as previous, dorsal view. J. Same as previous, left lateral view. 


\section{Remarks}

Considering the shape of the prongs of the forked projection of segment 1 of male, and the spine-like setae on the lateral surface of abdominal tergites 2 and 3, and pending the observation of additional specimens, we consider that the species briefly described and illustrated by Tjeder (1992) is D. tjederi gen. et sp. nov.

\section{Dorsomitus sp. $q$}

\section{Material examined}

MALAWI: 1 + , 4-5 Dec. 1983, P.U. EXPED. leg. (SANC NEUR00393).

SOUTH AFRICA: 1 q, Louis Trichardt (“Trichardtsdal”), -24.10, 30.24, alt. 637 m, 9 Jan. 1982, R.G. Oberprieler leg. (SANC NEUR00079); 1 क, Ben Lavin Nature Reserve, -23.13, 29.93, alt. 892 m, 19 Jan. 1998, M.D. Picker leg. (SANC NEUR12438).

SWAZILAND: 2 우, Lugaganene Manzini, -26.39, 31.21, 6 Feb. 1996, C. Saunders leg. (SANC NEUR12439).

ZIMBABWE: 1 9, Lawrenceville, -19.03, 32.73, alt. 1500 m, 6 Dec. 1994, N.J.S. Duke leg. (SANC NEUR01985).

\section{Description}

This description is based on a female collected in Zimbabwe (Fig. 3A-C), which seems to be better preserved than other specimens observed. It is suspected to represent the female of Dorsomitus tjederi gen. et sp. nov., but additional material is needed to confirm this assignation.

Coloration. Grey. Head, thorax and legs with same markings as male of Dorsomitus tjederi gen. et sp. nov. From abdominal segment 3, tergites with transverse dark lines: anterior line black, interrupted dorsally; second line brown entire; third line black, interrupted dorsally; fourth line light brown, entire, not very visible; fifth line black, interrupted dorsally; sixth line black, entire (Fig. 3B). Third abdominal sternite shorter than in male of D. tjederi gen. et sp. nov., with two latero-angular black shiny markings (Fig. 3C). Disc with characteristic brown markings and posterior margin bordered with black. Abdominal tergites with very sparse hairs.

Some other specimens have a dark brown coloration and abdominal tergite 3 with two lateral yellow markings (Fig. 3D-F). However, most of the color and shape differences observed could be due to postmortem discoloration and distortion - ascalphids often discolor significantly after preservation. The patterns in living specimens are magnificent, but soon fade, so apart from specific marks, other patterns could be misleading. Consequently, additional material is needed to associate males and females with certainty.

\section{Remark}

The two species of Dorsomitus gen. nov. are well characterized by the shape of the first abdominal tergite and the pubescence on the second and third abdominal tergites of males. However, the present state of knowledge makes it impossible to associate the examined females to either Dorsomitus neavei gen. nov. or $D$. tjederi gen. et sp. nov. with certainty. The description provided above is based on the examination of six females whose specific status remains unclear, although it is likely that they belong to one or both of the species of Dorsomitus gen. nov. described herein. 


\section{Discussion}

Kimmins (1949) described the species Disparomitus neavei on the basis of the shape of the first abdominal tergite that is developed dorsally into a forked projection. However, in Disparomitus (revision in progress), the first abdominal tergite is not as elevated and has a quite different saddle-shaped expansion. Moreover, the third abdominal sternite has a single straight black longitudinal line, the labial palp bears a sensory pit, and the parameres are prolonged ventrally by a carina that can be reflected laterally. Considering these differences, it appears justified to consider that Disparomitus neavei does not belong to the genus Disparomitus and must be transferred to another genus. Besides Disparomitus, two other genera, Fillus and Acmonotus, have the first abdominal tergite modified, but they don't possess the combination of characters manifest in Dorsomitus gen. nov., including the shape of the first abdominal tergite, the coloration of abdominal sternites or the shape of the male parameres. In Dixonotus Kimmins, 1950, the pair of divergent tapering bristly processes is borne by the second abdominal tergite (Kimmins 1950). Consequently, Dorsomitus gen. nov. must be considered as a valid genus well characterized by morphological apomorphies.

Van der Weele (1909) based the description of Suphalomitus buyssoni van der Weele, 1909 on the examination of three specimens labelled as types. One of them, supposedly in MNHN in Paris, was not located in the collection of this museum. The two other specimens examined belong to two different genera. One of them, in NHMUK, is a female that probably belongs to the genus Stephanolasca van der Weele, 1909 and the other, collected in the Taru desert in southern Kenya and housed in MNHN,
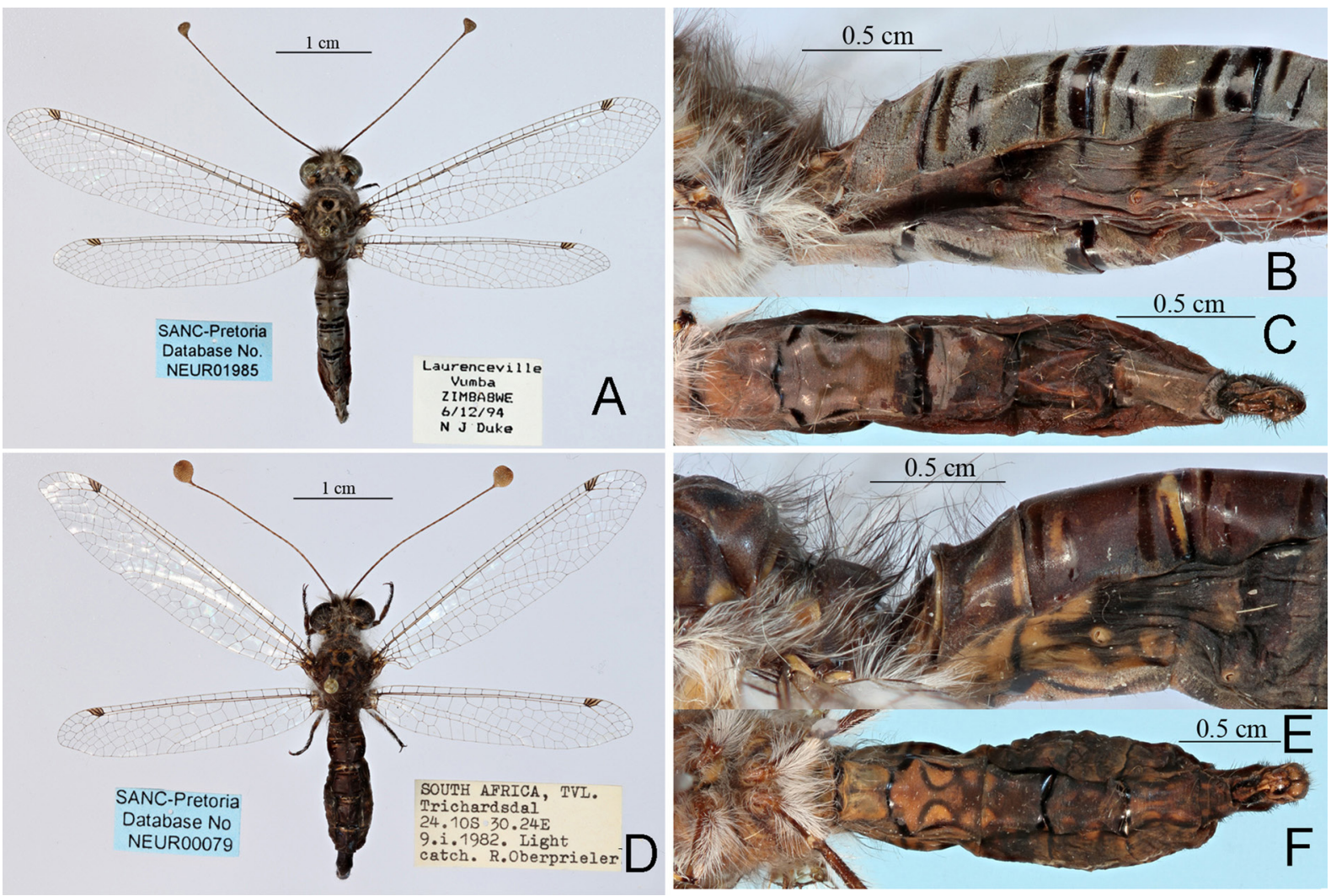

Fig. 3. Females of Dorsomitus gen. nov. A. Habitus of Dorsomitus gen. nov. sp. from Zimbabwe. B. Same as previous, left lateral view of base of abdomen. C. Same as previous, ventral view of abdomen. D. Habitus of Dorsomitus gen. nov. sp. from South Africa. E. Same as previous, left lateral view of base of abdomen. F. Same as previous, ventral view of abdomen. 
belongs to an unidentified genus. This latter specimen, with tip of abdomen missing (possibly dissected by van der Weele), was designated by van der Weele as the male of the female $S$. buyssoni. Concerning this last specimen, it should be noted that the third abdominal sternite harbors a marking very similar to the one of Dorsomitus gen. nov. and its relative length is also the same as in male Dorsomitus gen. nov. However, if the sex determination made by van der Weele is correct, we consider that the shape of the first abdominal tergite, which is weakly sclerotized and divided along the dorsal midline into a pair of dorso-lateral plates and not developed dorsally into a forked projection, clearly differentiates it from Dorsomitus gen. nov. Examination of this specimen shows that the color pattern of the third abdominal sternite in Dorsomitus gen. nov. is very probably shared with another genus. In the case of females, the separation of both genera is currently not possible and necessitates the examination of additional material.

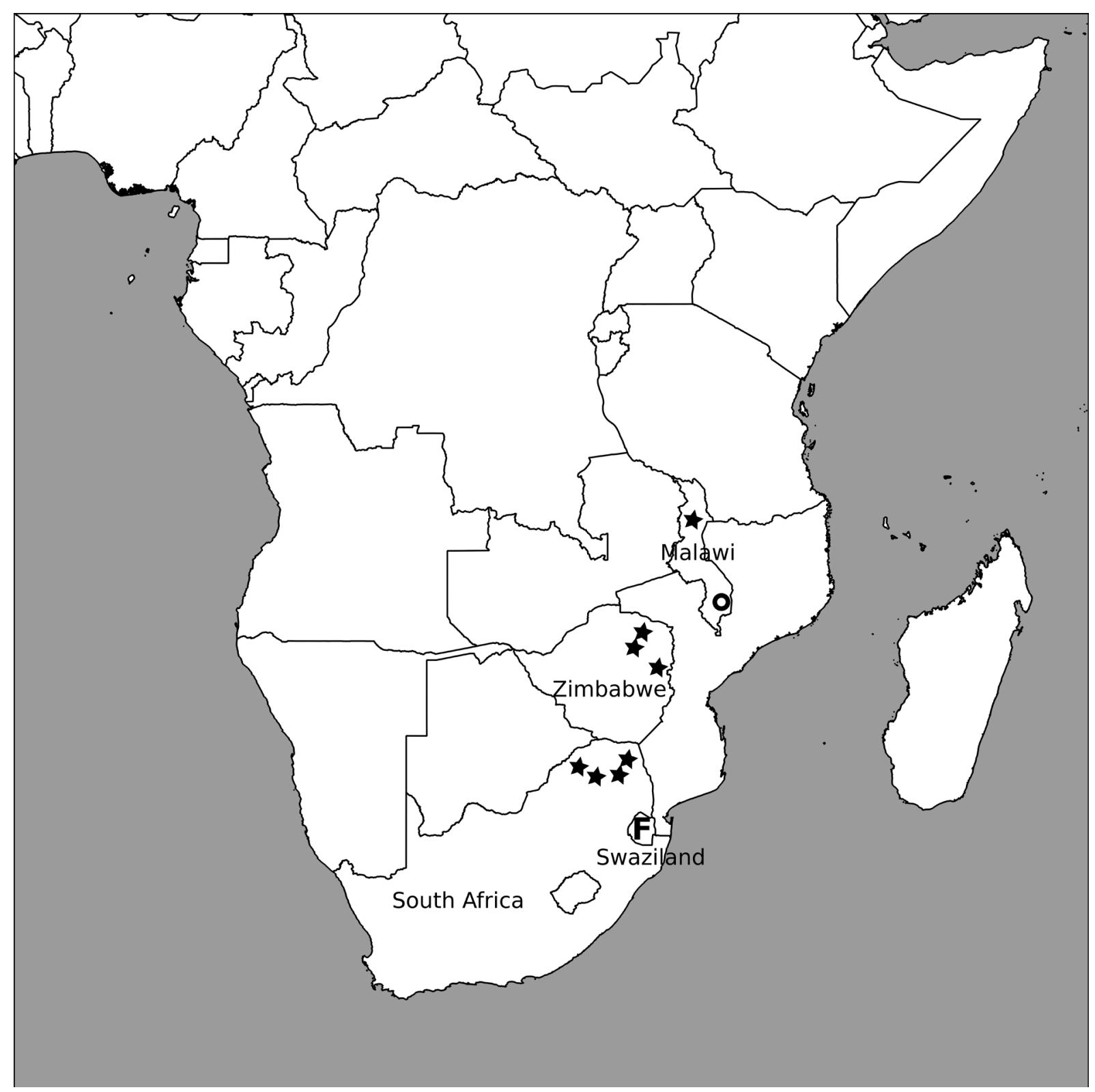

Fig. 4. Collection localities of males of Dorsomitus neavei (Kimmins, 1949) gen. et comb. nov. (circle), D. tjederi sp. nov. (stars) and Dorsomitus sp. 9 in Swaziland (F). 
Dorsomitus gen. nov. is poorly represented in collections. Only two specimens belonging to this genus have been found in the main European insect collections, and 17 additional individuals are in the SANC. Considering the known collection localities, the area of distribution seems to be restricted to the southeastern part of Africa.

\section{Acknowledgements}

We are grateful to Jean Legrand (MNHN), Antoine Mantilleri (MNHN) and Benjamin Price (NHMUK), for access to collections under their care and/or loans of specimens. We are grateful to the reviewers for their constructive and insightful comments.

\section{References}

Aberlenc H.P. 1980. Une nouvelle méthode d'éclairage pour l'examen des insectes. L'Entomologiste 36: $81-84$.

Aspöck U. \& Aspöck H. 2008. Phylogenetic relevance of the genital sclerites of the Neuropterida (Insecta: Holometabola). Systematic Entomology 33: 97-127. https://doi.org/10.1111/j.1365-3113.2007.00396.x

Kimmins D.E. 1949. Notes on Ascalaphidae in the British Museum collections, with descriptions of new species. The Annals and Magazine of Natural History 13: 1-29.

https://doi.org/10.1080/00222934908653955

Kimmins D.E. 1950. Some new African Ascalaphidae (Neuroptera). Annals and Magazine of Natural History 12: 242-252.

Mansell M.W. 2000. The Owlflies (Neuroptera: Ascalaphidae) of South Africa. Agricultural Research Council, Pretoria. Available from http://www.ru.ac.za/media/rhodesuniversity/resources/ martin/ascalaphidae.html [accessed 19 Feb. 2018].

Michel B. \& Akoudjin M. 2013. Overview of the knowledge of antlions and owlflies (Neuroptera: Myrmeleontidae, Ascalaphidae) of West Africa. In: de Freiras Martins A.M. \& Ventura M. (eds) Proceedings of the XI International Symposium of Neuropterology, Açoreana Supplement 9: 39-56. Sociedade Afonso Chaves, Ponta Delgada, Portugal.

Michel B. 2012. First record of the genus Kimulodes Tjeder \& Hansson in West Africa with description of a new species (Neuroptera, Ascalaphidae). Zootaxa 3497: 37-40. https://doi.org/10.5281/zenodo.282457

Navás L. 1913. Sinopsis de los Ascaláfidos. Publicacions de l'Institut de Ciencies 3: 1-99.

https://doi.org/10.5962/bhl.title. 8510

Navás L. 1919. Algunos insectos Neurópteros de la República Argentina. Serie tercera. Revista de la Real Academia de Ciencias Exactas Físicas y Naturales de Madrid 17: 287-305.

New T.R. 1986. A review of the biology of Neuroptera Planipennia. Neuroptera International Supplemental series 1: 1-56.

Oswald J.D. 2015. Neuropterida species of the world.

Available from http://lacewing.tamu.edu/SpeciesCatalog/Main [accessed 15 March 2017].

Prost A. 2013. The genus Ascalaphus (Fabricius, 1775) (Neuroptera, Ascalaphidae) in Africa. In: de Freiras Martins A.M. \& Ventura M. (eds) Proceedings of the XIth International Symposium of Neuropterology, Açoreana Supplement 9: 57-72. Sociedade Afonso Chaves, Ponta Delgada, Portugal.

Tjeder B. 1977. Distal abdominal segments and sclerotized parts of genitalia in Ascalaphidae (Neuroptera). Annales Entomologici Fennici 43: 61-65. 
Tjeder B. 1992. The Ascalaphidae of the Afrotropical Region (Neuroptera). 1. External morphology and bionomics of the family Ascalaphidae, and taxonomy of the subfamily Haplogleniinae including the tribes Proctolyrini n. tribe, Melambrotini n. tribe, Campylophlebini n. tribe, Tmesibasini n. tribe, Allocormodini n. tribe, and Ululomyiini n. tribe of Ascalaphinae. Entomologica Scandinavica Supplement 41: 7-169.

Tjeder B. \& Hansson C. 1992. The Ascalaphidae of the Afrotropical Region (Neuroptera). 2. Revision of the tribe Ascalaphini (subfam. Ascalaphinae) excluding the genus Ascalaphus Fabricius. Entomologica Scandinavica Supplement 41: 173-237.

van der Weele H.W. 1909. Collections zoologiques du Baron Edm. de Selys Longchamps. Catalogue Systématique et Descriptif, fasc. VIII: Ascalaphiden. Hayek, Brussels.

Manuscript received: 12 June 2017

Manuscript accepted: 11 September 2017

Published on: 14 March 2018

Topic editor: Gavin Broad

Desk editor: Chloë Chester

Printed versions of all papers are also deposited in the libraries of the institutes that are members of the EJT consortium: Muséum national d'Histoire naturelle, Paris, France; Botanic Garden Meise, Belgium; Royal Museum for Central Africa, Tervuren, Belgium; Natural History Museum, London, United Kingdom; Royal Belgian Institute of Natural Sciences, Brussels, Belgium; Natural History Museum of Denmark, Copenhagen, Denmark; Naturalis Biodiversity Center, Leiden, the Netherlands; Museo Nacional de Ciencias Naturales-CSIC, Madrid, Spain; Real Jardín Botánico de Madrid CSIC, Spain. 